University of Nebraska - Lincoln

DigitalCommons@University of Nebraska - Lincoln

Agronomy \& Horticulture -- Faculty Publications

Agronomy and Horticulture Department

3-1982

Performance of Blends of Short, Medium, and Tall Sorghum for Forage

Herman J. Gorz

United States Department of Agriculture

Francis A. Haskins

University of Nebraska-Lincoln, fhaskins@neb.rr.com

Follow this and additional works at: https://digitalcommons.unl.edu/agronomyfacpub

Part of the Plant Sciences Commons

Gorz, Herman J. and Haskins, Francis A., "Performance of Blends of Short, Medium, and Tall Sorghum for Forage" (1982). Agronomy \& Horticulture -- Faculty Publications. 240.

https://digitalcommons.unl.edu/agronomyfacpub/240

This Article is brought to you for free and open access by the Agronomy and Horticulture Department at DigitalCommons@University of Nebraska - Lincoln. It has been accepted for inclusion in Agronomy \& Horticulture -Faculty Publications by an authorized administrator of DigitalCommons@University of Nebraska - Lincoln. 


\title{
Performance of Blends of Short, Medium, and Tall Sorghum for Forage $^{1}$
}

\author{
H. J. Gorz and F. A. Haskins ${ }^{2}$
}

\begin{abstract}
This study was conducted to evaluate a wider range of plant types and agronomic and quality traits than had been previously reported for blends of sorghum [Sorghum bicolor (L.) Moench]. Three groups of sorghum cultivars and hybrids, each including a 1-dwarf (tall), a 2-dwarf (medium), and a 3-dwarf (short) sorghum, were used in a 2-year study. Within each group the following seven blends were compared: tall $(T)$, me$\operatorname{dium}(M)$, and short $(S) ; T$ and $M ; T$ and $S ; M$ and $S ; T$ alone; $M$ alone; and $S$ alone. Principal emphasis was given to total dry matter (DM) production (sum of leaves, stems, and heads). It was concluded that blends consisting of entries differing in stature had no significant DM yield advantage over pure stands of $T$ types. Yields of leaf and stem digestible dry matter and crude protein were closely correlated with leaf and stem DM yields. Yields of DM per stalk for $S$ plants were usually highest when these plants were grown in pure stand, but DM yields/stalk for $M$ and $T$ entries were generally highest when these entries were grown in blends.
\end{abstract}

Additional index words: Sorghum bicolor (L.) Moench, Forage yield, Crude protein, Digestibility, Intercropping.

E XTENSIVE studies on the theory and practice of many kinds of intercropping have been published (4), but little published information is available on the intraspecific intercropping of sorghum [Sorghum bicolor (L.) Moench] cultivars and hybrids. In a 5-year study at Hays, Kansas, Ross (6) compared the yields of five grain sorghum hybrids with yields of all possible $1: 1$ blends derived from them. No consistent advantage in grain yield was observed for any of the blends. Reich and Atkins (5) studied the performance of grain sorghum parental lines and hybrids, and two-component parental blends and hybrid blends in nine lowa environments over 2 years. Averaged across all environments, most of the blends produced somewhat more grain than the mean of pure stand yields of their components. In each environment except one, however, the highest yicld was produced by a hybrid grown in pure stand. More recently Skidmore and Hagen (7) studied the response of 2-dwarf and 3-dwarf isogenic hybrids of 'RS702' grain sorghum grown with the taller 2-dwarf hybrid as a shelter for the 3-dwarf hybrid. They observed that yields of grain and forage per culm of the 2-dwarf hybrid were higher in blends consisting of 13 or $25 \% 2$-dwarf seed than in a pure stand of the 2-dwarf hybrid. However, for the 3-dwarf hybrid yields of grain and forage per culm with this hybrid comprising 87 or $75 \%$ of the blend were not significantly different from yields per culm in a pure stand.

The cited studies of Ross and of Reich and Atkins employed only grain sorghums; that of Skidmore and Hagen involved a single 2-dwarf, 3-dwarf pair of entries. In the study reported in this paper a wider range of plant types was utilized, and a more extensive list of traits was examined.

\section{MATERIALS AND METHODS}

Three groups, each consisting of three different entries, were included in this study. One of the entries in each group was a 1dwarf (tall) forage sorghum cultivar or hybrid; one was a 2-dwarf (medium) hybrid resulting from crosses involving germplasm from 'Early Hegari' and the forage sorghum cultivars 'Atlas', 'Rox', 'Sart', and 'White Collier'; and the third was a 3-dwarf grain sorghum hybrid (Table 1). Entries were chosen such that in each group the short (S) entry matured before the medium (M) entry which matured before the tall (T) entry. Within each group seven blends were prepared (Table 2). Blend tms, for example, consisted of a blend of the T, $M$, and $S$ entries, $t m$ was a blend of $T$ and $M$, etc. In some of the analyses the 12 individual components of the blends were considered. The relationship of these components to the blends also is shown in Table 2. The

'Contribution from USDA-ARS, and the Nebraska Agric. Exp. Stn., Lincoln. Published as Paper No. 6143, Journal Series, Nebraska Agric Exp. Stn. Received 26 Jan. 1981. The work reported was conducted under Nebraska Agric. Exp. Stn. Projects 12-088 and 12-114.

${ }^{2}$ Supervisory research geneticist, USDA-ARS and professor of Agronomy; and George Holmes professor of Agronomy; Univ. of Nebraska, Lincoln, NE 68583, respectively. 
Table 1. Groups of entries used in the sorghum blend experiment.

\begin{tabular}{lllc}
\hline $\begin{array}{c}\text { Group } \\
\text { no. }\end{array}$ & $\begin{array}{l}\text { Height } \\
\text { class }\end{array}$ & Entry & $\begin{array}{c}\text { Height } \dagger \\
\text { (cm) }\end{array}$ \\
\hline I & T (tall) & White Collier & 248 \\
& M (medium) & $\begin{array}{l}\text { Early Hegari-Atlas } \times \\
\text { Early Hegari-Rox }\end{array}$ & 166 \\
& S (short) & RS 625 & 107 \\
II & T & N4692 $\times$ White Collier & 254 \\
& M & Early Hegari-White Collier $\times$ & \\
& Early Hegari-Rox & 178 \\
III & $\mathrm{S}$ & RS 626 & 111 \\
& $\mathrm{~T}$ & N4692 $\times$ N6229 & 293 \\
& $\mathrm{M}$ & Early Hegari-White Collier $\times$ & 172 \\
& $\mathrm{~S}$ & Early Hegari-Sart & 121 \\
\hline
\end{tabular}

$\dagger$ Two-year means, entries grown in pure stands.

T entry in each group, for example, appeared in Blends tms, tm, ts, and $t$ as Components 1, 4, 6, and 10, respectively.

The experiment was planted at the University of Nebraska Field Laboratory, Mcad, Nebraska, on 31 May 1977 and 25 May 1978. Four replications were planted each year in plots consisting of two 9-m rows spaced $76 \mathrm{~cm}$ apart. In 1977 the experiment was planted in a randomized complete block design with a split plot arrangement, with groups as main plots and blends as subplots. Seeding rate was $4.5 \mathrm{~g}$ of seed per row, and seedlings were thinned to a spacing of about $10 \mathrm{~cm}$ after emergence. Blends of two or three entries consisted of equal weights of seed of the appropriate entries, and a total seed weight of $4.5 \mathrm{~g}$ per row. It was intended that a split-plot arrangement be used again in 1978, but through a misunderstanding, the 1978 experiment was planted instead as a simple randomized complete block design. As in 1977, four replications were planted. To eliminate the need for thinning, and thus to guard against the possibility of preferential removal of T, M, or S seedlings during thinning, germination of each seed lot was determined, and appropriate numbers of seeds were planted to provide equal numbers of viable seeds of each entry in blends containing more than one entry, and a total of 100 viable seeds per $9-\mathrm{m}$ row.

Plants were harvested for yield determination on 5 and 6 Oct. 1977 and 25 and 26 Sept. 1978. These dates preceded the occurrence of killing frost but followed the attainment of physiological maturity of most plants of all entries. A 4.5-m section was handharvested from one row of each plot, plants were sorted into $\mathrm{T}$, $M$, and $S$ entries, and stalk counts and weights of each entry were recorded. Heads were then cut off and weighed by entry, and a dry weight sample consisting of a few heads was taken for each entry in each plot. Dry weight samples of stems and leaves also were taken for each entry within each plot. These samples usually consisted of two T or M plants, or three to five S plants, from which the heads had been removed. Leaves (primarily the blade portion) were stripped from these plants and weighed, and stems (with remnants of leaf sheaths) were then chopped with a small forage chopper and weighed. All dry matter samples were dried to constant weight in a forced draft oven at about $65 \mathrm{C}$.

Leaf and stem dry weight samples were further used for determinations of crude protein content by the Kjeldahl procedure (1) and in vitro dry matter digestibility (IVDMD) by the twostage procedure of Tilley and Terry (8). Subsamples of the dry matter samples were ground through the $1-\mathrm{mm}$ screen of a Wiley ${ }^{3}$ mill for these procedures.

Plant heights (from soil surface to panicle tips) also were recorded for each entry in each plot at the time of harvest, both in

${ }^{3}$ Mention of a trademark or proprictary product does not constitute a guarantee or warranty of the product by the USDA or the Univ. of Nebraska and does not imply its approval to the exclusion of other products that may also be suitable.
Table 2. Relationship of components to blends. The symbols $T$, $M$, and $S$ indicate tall, medium, and short entries, respectively.

\begin{tabular}{lcl} 
& \multicolumn{2}{c}{ Component } \\
\cline { 2 - 3 } Blend & Designation & Description \\
\hline tms & 1 & T with M and S \\
& 2 & M with T and S \\
tm & 3 & S with T and M \\
& 4 & T with M \\
ts & 5 & M with T \\
& 6 & T with S \\
$\mathrm{ms}$ & 7 & S with T \\
& 8 & M with S \\
$\mathrm{t}$ & 9 & S with M \\
$\mathrm{m}$ & 10 & T alone \\
$\mathrm{S}$ & 11 & M alone \\
\hline
\end{tabular}

1977 and 1978. In addition, lodging scores were assigned in 1977 only, and heading dates were recorded in 1978 only.

In conformity with the arrangements of the field plots, the 1977 and 1978 studies were analyzed as split plot and randomized complete block experiments, respectively.

\section{RESULTS AND DISCUSSION}

Analyses of variance revealed significant differences both among the three groups and among the seven blends for most of the traits investigated (Table 3). Group $\times$ blend interactions also were significant for most of the traits in 1977 and for several in 1978. The traits of greatest interest in this study were the dry matter yields of leaves, stems, and heads, and the sum of these three parts, and crude protein and IVDMD percentages of leaves and stems. Most of the group $\times$ blend interactions involving these traits were nonsignificant, and those that were significant statistically had little practical effect on our interpretation of the data. For this reason, and in the interest of brevity, we have averaged blends, the category of major interest, over groups, on which less emphasis was placed (Table 4).

In terms of dry matter (DM) yields of leaves, blend $t$ was the highest in 1977 and next to the highest in 1978. Stem DM yields were considerably higher than leaf yields; blend $\mathrm{t}$ was clearly the highest in stem yields. Blend $\mathrm{s}$ was consistently lowest in yields of leaves and stems. Head yields generally varied less among the blends than leaf and stem yields. Within the comparatively narrow range observed in yields of heads, blend $\mathrm{tm}$ and $\mathrm{m}$ were most consistently at or near the top. Blend $t$ generally did not rank highest in head yield, but in no case in these experiments was this entry significantly lower in head yield than the unmixed grain sorghum entry (blend s). In total DM yield, blend $t$ was highest in both years. Examination of the blend means by groups for each year revealed that in five of the six group-year combinations, blend $t$ produced the highest total yield, and in the sixth the total yield of this blend did not differ significantly from that of the highest yielding blend. Clearly, in this test no advantage in DM yield resulted from planting a mixture of entries differing in height as opposed to planting a pure stand of tall forage sorghum.

Significant differences in stalk count existed among blends and groups in 1977 and among groups in 1978 
Table 3. Significance of differences among three groups and among seven blends with respect to 23 traits, in 1977 and 1978.

\begin{tabular}{|c|c|c|c|c|c|c|}
\hline \multirow[b]{2}{*}{ Trait } & \multicolumn{3}{|c|}{1977} & \multicolumn{3}{|c|}{1978} \\
\hline & Groups & Blends & $\underset{\text { blend }}{\text { Group }} \times$ & Groups & Blends & $\underset{\text { blend }}{\text { Group } \times}$ \\
\hline No. of stalks/plot & $* *$ & $* *$ & $* *$ & $* *$ & NS & NS \\
\hline Plant height & $* *$ & $* *$ & $* *$ & $* *$ & $* *$ & $* *$ \\
\hline Dry matter yield-leaves & $* *$ & ** & $* *$ & $* *$ & $* *$ & $* *$ \\
\hline Dry matter yield-stems & $*$ & $* *$ & $* *$ & $* *$ & $* *$ & NS \\
\hline Dry matter yield-heads & $* *$ & $* *$ & NS & $* *$ & $*$ & NS \\
\hline Dry matter yield-total & $* *$ & $* *$ & NS & $* *$ & $* *$ & NS \\
\hline Dry matter $(\%)$-leaves & NS & NS & NS & NS & NS & NS \\
\hline Dry matter $(\%)$-stems & $* *$ & $* *$ & NS & $* *$ & $* *$ & $*$ \\
\hline Dry matter $(\%)$-heads & $* *$ & $* *$ & $* *$ & $* *$ & NS & NS \\
\hline Dry matter $(\%)$-total & $* *$ & $* *$ & $* *$ & $* *$ & $* *$ & NS \\
\hline IVDMD (\%)-leaves & $* *$ & $* *$ & NS & ** & $* *$ & NS \\
\hline IVDMD $(\%)$-stems & ** & ** & NS & $* *$ & $* *$ & NS \\
\hline Digestible dry matter yield-leaves & $* *$ & $* *$ & $* *$ & $* *$ & ** & $*$ \\
\hline Digestible dry matter yield-stems & NS & $* *$ & $* *$ & NS & $* *$ & NS \\
\hline Crude protein $(\%)$-leaves & NS & $* *$ & ** & $* *$ & ** & $* *$ \\
\hline Crude protein $(\%)$-stems & $* *$ & ** & $*$ & $*$ & ** & NS \\
\hline Crude protein yield-leaves & $* *$ & $* *$ & ** & NS & $* *$ & NS \\
\hline Crude protein yield-stems & ** & ** & ** & $*$ & ** & NS \\
\hline Fraction of dry matter contributed-leaves & $* *$ & ** & ** & NS & ** & $*$ \\
\hline Fraction of dry matter contributed-stems & ** & ** & ** & $* *$ & ** & NS \\
\hline Fraction of dry matter contributed-heads & $* *$ & ** & ** & $* *$ & ** & NS \\
\hline Lodging & ** & ** & ** & -. & -- & -- \\
\hline Heading date & - & -- & - & ** & ** & $* *$ \\
\hline
\end{tabular}

* and ** indicate significance at the 0.05 and 0.01 levels of probability, respectively; NS indicates not significant.

Table 4. Blend means for dry matter yield of leaves, stems, and heads, and for percentages of crude protein and IVDMD in leaves and stems, 1977 and 1978.

\begin{tabular}{|c|c|c|c|c|c|c|c|c|c|}
\hline \multirow[b]{2}{*}{ Year } & \multirow[b]{2}{*}{ Blend } & \multicolumn{4}{|c|}{ Dry matter yield } & \multicolumn{2}{|c|}{ Crude protein } & \multicolumn{2}{|c|}{ IVDMD } \\
\hline & & Leaves & Stems & Heads & Total & Leaves & Stems & Leaves & Stems \\
\hline & & $\ldots$ & met & ha & & & - & & \\
\hline \multirow[t]{7}{*}{1977} & tms & $2.76 b^{*}$ & $6.14 \mathrm{c}$ & $5.98 \mathrm{~cd}$ & $14.88 \mathrm{~b}$ & $12.7 \mathrm{bc}$ & $3.0 \mathrm{c}$ & $53.7 \mathrm{bc}$ & $51.6 \mathrm{ab}$ \\
\hline & $\mathrm{tm}$ & $3.32 \mathrm{a}$ & $7.55 \mathrm{~b}$ & $7.80 \mathrm{a}$ & $18.67 \mathrm{a}$ & $12.3 \mathrm{~cd}$ & $2.7 \mathrm{c}$ & $53.0 \mathrm{~cd}$ & $50.7 \mathrm{~b}$ \\
\hline & ts & $2.63 \mathrm{~b}$ & $6.37 \mathrm{c}$ & $5.76 \mathrm{~cd}$ & $14.76 \mathrm{~b}$ & $13.2 \mathrm{ab}$ & $3.6 \mathrm{~b}$ & $55.3 \mathrm{ab}$ & $52.5 \mathrm{ab}$ \\
\hline & $\mathrm{ms}$ & $2.31 \mathrm{~b}$ & $4.45 \mathrm{e}$ & $6.71 \mathrm{bc}$ & $13.47 \mathrm{~b}$ & $11.9 \mathrm{~d}$ & $3.0 \mathrm{c}$ & $51.3 \mathrm{~d}$ & $48.5 \mathrm{c}$ \\
\hline & $\mathrm{t}$ & $3.72 \mathrm{a}$ & $9.50 \mathrm{a}$ & $6.14 \mathrm{~cd}$ & $19.35 \mathrm{a}$ & $13.3 \mathrm{a}$ & $3.1 \mathrm{c}$ & $56.5 \mathrm{a}$ & $53.7 \mathrm{a}$ \\
\hline & $\mathrm{m}$ & $2.54 \mathrm{~b}$ & $5.26 \mathrm{~d}$ & $7.31 \mathrm{ab}$ & $15.10 \mathrm{~b}$ & $12.2 \mathrm{~cd}$ & $2.9 \mathrm{c}$ & $52.3 \mathrm{~cd}$ & $47.0 \mathrm{c}$ \\
\hline & s & $1.39 \mathrm{c}$ & $2.71 \mathrm{f}$ & $5.44 \mathrm{~d}$ & $9.54 \mathrm{c}$ & $13.4 \mathrm{a}$ & $4.6 \mathrm{a}$ & $52.5 \mathrm{~cd}$ & $51.2 \mathrm{~b}$ \\
\hline \multirow[t]{7}{*}{1978} & $\mathrm{tms}$ & $2.06 \mathrm{~b}$ & $5.42 \mathrm{~d}$ & $5.33 \mathrm{~b}$ & $12.80 \mathrm{~d}$ & $8.0 \mathrm{bc}$ & $1.9 \mathrm{bc}$ & $50.7 \mathrm{~b}$ & $58.4 \mathrm{bc}$ \\
\hline & $\mathrm{tm}$ & $2.20 \mathrm{~b}$ & $8.58 \mathrm{~b}$ & $6.66 \mathrm{ab}$ & $17.44 \mathrm{~b}$ & $7.9 \mathrm{c}$ & $1.5 \mathrm{c}$ & $52.4 \mathrm{ab}$ & $59.7 \mathrm{~b}$ \\
\hline & ts & $2.03 \mathrm{~b}$ & $6.58 \mathrm{c}$ & $5.59 \mathrm{~b}$ & $14.20 \mathrm{~cd}$ & $9.0 \mathrm{bc}$ & $2.1 \mathrm{~b}$ & $52.0 \mathrm{ab}$ & $59.2 \mathrm{~b}$ \\
\hline & $\mathrm{ms}$ & $2.18 \mathrm{~b}$ & $5.18 \mathrm{~d}$ & $6.65 \mathrm{ab}$ & $14.01 \mathrm{~cd}$ & $8.3 \mathrm{bc}$ & $2.4 \mathrm{~b}$ & $50.0 \mathrm{~b}$ & $56.1 \mathrm{~cd}$ \\
\hline & $\mathrm{t}$ & $2.36 \mathrm{~b}$ & $11.08 \mathrm{a}$ & $6.26 \mathrm{ab}$ & $19.70 \mathrm{a}$ & $9.1 \mathrm{~b}$ & $1.5 \mathrm{c}$ & $53.9 \mathrm{a}$ & $62.2 \mathrm{a}$ \\
\hline & $\mathrm{m}$ & $2.73 \mathrm{a}$ & $5.87 \mathrm{~cd}$ & $7.40 \mathrm{a}$ & $16.00 \mathrm{bc}$ & $8.1 \mathrm{bc}$ & $2.2 \mathrm{~b}$ & $49.9 \mathrm{~b}$ & $57.5 \mathrm{bc}$ \\
\hline & s & $1.48 \mathrm{c}$ & $3.23 \mathrm{e}$ & $6.12 \mathrm{ab}$ & $10.83 \mathrm{e}$ & $10.5 \mathrm{a}$ & $3.0 \mathrm{a}$ & $51.3 \mathrm{~b}$ & $55.0 \mathrm{~d}$ \\
\hline
\end{tabular}

* Means within columns and years followed by the same letter do not differ at the 0.05 probability level according to Duncan's Multiple Range Test.

(Table 3), and it would be reasonable to question whether variation in yield was associated with these differences. Correlation coefficients were calculated for the relationship between total DM yields and stalk counts, based on the 21 blend-group means for each of these two traits. Values for $r$ were 0.191 for 1977 and -0.264 for 1978 . It appears, therefore, that total DM yield was not closely related to stalk count in these experiments.

Determinations of crude protein percentage in leaf samples revealed blend means that ranged from 11.9 to 13.4 in 1977 and 7.9 to 10.5 in 1978 (Table 4). Comparable ranges for stem protein percentage were 2.7 to 4.6 in 1977 and 1.5 to 3.0 in 1978 . The most consistent feature of the patterns of leaf and stem protein percentage was the general superiority of blend $\mathrm{s}$.

In 1977 the range in blend means for IVDMD of leaf samples was 51.3 to $56.5 \%$ (Table 4); in 1978 the range was 49.9 to $53.9 \%$. For stems, IVDMD ranges in 1977 and 1978 were 47.0 to $53.7 \%$ and 55.0 to $62.2 \%$, respectively. Blend t was consistently superior in both leaf and stem IVDMD

Based on DM yields and percentages of IVDMD and crude protein in leaves and stems, yields of leaf and stem digestible dry matter (DDM) and protein were calculated for each plot. The resulting means ( 21 blend-group means for each trait in each year) were compared with leaf and stem DM yields by calculation of correlation coefficients. As shown by the $r$ values in Table 5, yields of DDM of leaves and stems were closely associated with leaf and stem DM yields in both years. The association of protein yields and DM yields was somewhat less close, especially in 1978 , but all of the $r$ values exceeded the 0.01 level of significance. It is apparent that in this study those blends that produced the highest yields of leaf and stem DM generally produced the highest yields of leaf and stem DDM and crude protein as well. 
Table 5. Correlation coefficients for the relationships of dry matter (DM) yield and yield of digestible dry matter (DDM) or crude protein (CP) based on blend-group means for leaves and stems; $n=21$ for each comparison.

\begin{tabular}{lcc}
\hline & \multicolumn{2}{c}{ Year } \\
\cline { 2 - 3 } Comparison & \multicolumn{1}{c}{1977} & 1978 \\
\hline & & \\
& & \\
DM yield and DDM yield-leaves & $0.996^{* *}$ & $0.981^{* *}$ \\
DM yield and DDM yield-stems & $0.992^{* *}$ & $0.990^{* *}$ \\
DM yield and CP yield--leaves & $0.993^{* *}$ & $0.793^{* *}$ \\
DM yield and CP yield-stems & $0.893^{* *}$ & $0.711^{* *}$ \\
\hline
\end{tabular}

** Significant at the 0.01 level of probability.

Protein and IVDMD percentages were not determined on the head samples collected in this study. We were, therefore, unable to draw any firm conclusions as to possible relationships between total yields of DDM or crude protein and total DM yields. Morrison (2) reported that sorghum heads contain $9.2 \%$ protein and that they are $74.3 \%$ digestible. Use of these values as constants allowed estimation of yields of head protein and DDM, and addition of these yields to leaf and stem values afforded approximation of total yields of protein and DDM. Analyses of these total yields permitted the tentative conclusion that, as was true for total DM yields (Table 4), no blend was significantly better than blend $t$ in total yield of either crude protein of DDM

Owen (3) and Ward et al. (9) have shown that in sorghum silage, percentage DM and DM intake are positively correlated. Thus percentage dry matter is of potential importance in forage sorghum production. Determinations of percentage DM for each blend-group combination revealed that blend $\mathrm{s}$ was highest in DM percentage in all three groups in both years. This result was not surprising, for the $\mathrm{S}$ entries were selected in part because they matured earlier than the $\mathrm{M}$ and $\mathrm{T}$ entries. However, it was somewhat surprising that the presence of $\mathrm{S}$ entries in other blends (i.e., blends tms, ts, and $\mathrm{ms}$ ) failed to effect any consistent, significant increase in DM percentage of the harvested forage of these blends (data not shown). This lack of consistent effect on DM percentage is doubtless related to the fact that in most blends of which they were a part, the $S$ entries made relatively minor (less than one-fifth) contributions to total yield.

Numerous traits were analyzed on the component basis. These analyses permitted a comparison of the performance of each entry planted alone with its performance in mixed plantings with either or both of the other entries in its group. For most of the traits these component analyses revealed significant differences among Groups I, II, and III and among the height categories, T, M, and S. Significant interactions between groups and height categories also occurred for most of the traits. Significant differences among components within height categories were encountered less frequently, especially in the $T$ and $M$ categories. We do not believe that the component analyses merit the presentation of detailed data or extensive discussion, but we do wish to comment briefly on the com- ponent analysis for DM yield per stalk. It seems reasonable to expect that an $S$ entry would produce more DM per stalk when grown alone than when grown with $\mathrm{M}$ or $\mathrm{T}$ entries, but $\mathrm{M}$ and $\mathrm{T}$ entries might be expected to produce higher yields per stalk when grown with entries of shorter stature. For each of the three height categories, three comparisons (Groups I, II, and III) were available in each of the 2 years, or a total of six comparisons per height category. In accordance with expectations, in five of the six comparisons involving the four $\mathrm{S}$ components (components 3, 7, 9, and 12, Table 2), component 12 (S alone) produced the highest DM yield per stalk. On the other hand, $\mathrm{M}$ alone (component 11) produced the highest yield per stalk in only one of the six comparisons involving the four $\mathrm{M}$ components, and $\mathrm{T}$ alone (component 10) produced the highest yield per stalk in only one of the six comparisons involving $\mathrm{T}$ components. In general, these results with $M$ and $T$ entries agreed with the observations of Skidmore and Hagen (7) on the behavior of the 2-dwarf component in a 2-dwarf, 3-dwarf mixed planting.

For the entire experiment the DM yield per stalk was only $84 \%$ as high in 1978 as in 1977 (104.6 compared to $125.2 \mathrm{~g} / \mathrm{stalk}$ ). In both years there were highly significant differences among Groups I, II, and III and among height categories $\mathrm{T}, \mathrm{M}$, and $\mathrm{S}$, and there were highly significant group $X$ height interactions with respect to yield per stalk. Despite these differences, the 36 component-group means (12 components and 3 groups) of 1977 were highly correlated $(r=0.942)$ with corresponding values for 1978 .

The principal conclusion to be drawn from this study is that in terms of forage production, blends consisting of entries varying in stature offered no significant advantages over pure stands of tall forage types.

\section{ACKNOWLEDGMENT}

The assistance of Roger I. Deaton of the University of Nebraska Biometrics and Information Systems Center in analyzing the data is gratefully acknowledged.

\section{REFERENCES}

1. Association of Official Agricultural Chemists. 1960. Official methods of analyses of the A. O. A. C. 9 th ed. A. O. A. C. Washington, D.C.

2. Morrison, F. B. 1956. Feeds and Feeding, 22nd ed., Morrison Publishing Co., Clinton, Iowa.

3. Owen, F. G. 1962. Effect of stage of maturity on the nutritive value of Atlas sorghum silage for lactating dairy cows. J. Dairy Sci. 45:62.5628.

4. Papendick, R. I., P. A. Sanchez, and G. B. Triplett, (ed.) 1976. Multiple Cropping. Am. Soc. Agron. Spec. Pub. 27, Am. Soc. Agron., Madison, Wisc.

5. Reich, V. H., and R. E. Atkins. 1970. Yield stability of four population types of grain sorghum, Sorghum bicolor (L.) Moench, in different environments. Crop Sci. 10:511-517.

6. Ross, W. M. 1965. Yicld of grain sorghum (Sorghum vulgare Pers.) hybrids alone and in blends. Crop Sci. 5:593-594.

7. Skidmore, E. L., and L. J. Hagen. 1978. Sheltering 3-dwarf with taller 2-dwarf grain sorghum. Phyton 36:7-14.

8. Tilley, J. M. A., and R. A. Terry. 1963. A two-stage technique for the in vitro digestion of forage crops. J. Br. Grassl. Soc. 18:104-111.

9. Ward. G. M., F. W. Boren, E. F. Smith, and J. R. Brethour. 1966. Relation between dry matter content and dry matter consumption of sorghum silage. J. Dairy Sci. 49:399-402. 